\title{
Insectivory in Potamotrygon signata (Chondrichthyes: Potamotrygonidae), an endemic freshwater stingray from the Parnaíba River basin, northeastern Brazil
}

\author{
Moro, G. ${ }^{a *}$, Charvet, $P^{b}$ and Rosa, RS. ${ }^{c}$ \\ aPrograma de Pós-graduação em Ciências Biológicas, Centro de Ciências Exatas e da Natureza - CCEN, \\ Universidade Federal da Paraíba - UFPB, Cidade Universitária, CEP 58059-900, João Pessoa, PB, Brazil

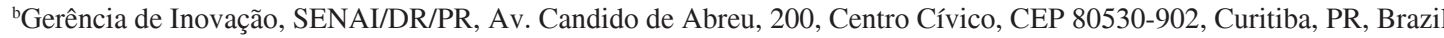 \\ 'Departamento de Sistemática e Ecologia, Centro de Ciências Exatas e da Natureza - CCEN, \\ Universidade Federal da Paraíba - UFPB, Cidade Universitária, CEP 58059-900, João Pessoa, PB, Brazil \\ *e-mail: g-moro@uol.com.br
}

Received November 28, 2011 - Accepted March 7, 2012 - Distributed November 30, 2012

\begin{abstract}
Potamotrygon signata is an endemic freshwater stingray species in the Parnaíba River basin, Brazil. After its original description, only citations in systematic lists were recorded in the literature and the biology of the species remains unknown, including the feeding habits. The aim of this study is to characterize the overall diet of $P$. signata based on analysing stomach contents and to provide preliminary information on intraspecific diet variability between sexes and maturity stages. The stomach contents of 56 specimens of $P$. signata were analyzed. The taxonomic identification of food items showed the presence of 13 prey orders, including insects, mollusks, crustaceans and teleost fish. The Index of Relative Importance (IRI\%) indicated P. signata as an insectivorous species, with a dominance of Diptera larvae (60.64\%) and Ephemeroptera nymphs (34.68\%). Differences in diet were observed between sexes, as well as between mature and immature individuals. The IRI\% of females showed a similar occurrence of Diptera and Ephemeroptera (47.12\% and $47.86 \%$, respectively), whereas for males, Ephemeroptera was the main item $(79.56 \%)$. Immature individuals showed a dominance of Diptera (76.20\%) while mature individuals showed a similar occurrence of Diptera (46.95\%) and Ephemeroptera (47.23\%). The observed sexual and ontogenetic differences in diet may be related to distinct nutritional requirements of males and females, and to the variation of morphological aspects of the oral apparatus and dentition of males and females and of immature individuals and adults. The essentially insectivorous diet of the species is possibly adaptively advantageous in the Caatinga semi-arid environment, where the availability of fish as prey may be subject to strong seasonal variation.
\end{abstract}

Keywords: caatinga biome, fish feeding, stomach contents.

\section{Insetivoria em Potamotrygon signata (Chondrichthyes: Potamotrygonidae), uma raia de água doce endêmica da bacia do rio Parnaíba, nordeste do Brasil}

\begin{abstract}
Resumo
Potamotrygon signata é uma espécie de raia de água doce endêmica da bacia do rio Parnaíba, Brasil. Após a sua descrição original, apenas citações em listas sistemáticas foram registradas na literatura e a biologia da espécie permanece desconhecida, incluindo os hábitos alimentares. Este estudo teve como objetivo caracterizar a dieta de $P$. signata com base na análise do conteúdo estomacal, e fornecer informações preliminares sobre a variabilidade intraespecífica da dieta entre os sexos e segundo os estádios de maturidade. O conteúdo estomacal de 56 espécimes de P. signata foi analisado. A identificação taxonômica dos itens alimentares revelou a presença de 13 ordens de presas, incluindo insetos, moluscos, crustáceos e peixes teleósteos. O Índice de Importância Relativa (IRI\%) indicou P. signata como uma espécie insetívora, com predominância de larvas de Diptera (60.64\%) e ninfas de Ephemeroptera (34.68\%). Diferenças na dieta entre os sexos foram observadas, bem como entre os indivíduos maduros e imaturos. A IRI\% das fêmeas mostrou uma ocorrência similar de Diptera e Ephemeroptera (47.12\% e 47.86\%, respectivamente), enquanto para os machos, Ephemeroptera foi o principal item (79.56\%). Indivíduos imaturos mostraram um predomínio de Diptera (76.20\%), enquanto indivíduos maduros apresentaram uma ocorrência similar de Diptera (46.95\%) e Ephemeroptera $(47.23 \%)$. As diferenças sexuais e ontogenéticas observadas na dieta podem estar relacionadas a diferentes necessidades nutricionais de machos e fêmeas, e à variação de aspectos morfológicos do aparelho bucal e dentição de machos e fêmeas e de indivíduos imaturos e maduros. A dieta essencialmente insetívora desta espécie possivelmente é uma vantagem adaptativa para esta espécie no ambiente semiárido da Caatinga, onde a disponibilidade de peixes como presa pode sofrer grandes variações sazonais.
\end{abstract}

Palavras-chave: bioma Caatinga, alimentação de peixes, conteúdo estomacal. 


\section{Introduction}

Assessing diet, based on analysing stomach contents, has become routine practice in the study of the ecology of fish (Hyslop, 1980; Cortés, 1997). Studies on the diet of skates and rays are relatively scarce when compared to those of sharks (Aguiar and Valentin, 2010). Even fewer studies deal specifically with feeding habits of the Neotropical freshwater stingrays (Potamotrygonidae). Achenbach and Achenbach (1976) reported the first observations related to feeding habits of potamotrygonids, in the Paraná River basin. The original description of Plesiotrygon iwamae Rosa et al. (1987), reported fish, crabs and insects as food items of this species. Lasso et al. (1996), in the Venezuelan llanos, investigated the diet of two species, Paratrygon aiereba (Müller and Henle, 1841) and Potamotrygon orbignyi (Castelnau, 1855), which respectively showed a diet dominated by fish and shrimp, as well as insects. A recent literature review on feeding studies of Brazilian elasmobranchs (Aguiar and Valentin, 2010) pointed out only three published papers on the diet and/or feeding behavior of potamotrygonids (Lonardoni et al., 2006; Garrone-Neto and Sazima, 2009a, 2009 b). Overlooked papers in this review were those by Shibuya et al. (2009), analyzing stomach contents of freshwater stingrays from the middle Negro River, and by Silva and Uieda (2007) and Lonardoni et al. (2009), on the feeding behavior of Potamotrygon falkneri Castex and Maciel, 1963 and Potamotrygon motoro (Natterer in Müller and Henle, 1841). After this review, two additional papers were published (Almeida et al., 2010; Moro et al., 2011), focusing on the diet of P. motoro and P. orbignyi, respectively.

The Parnaíba's stingray Potamotrygon signata Garman, 1913 is one of the endemic species in the Parnaíba River basin (Carvalho et al., 2003; Rosa et al., 2003, 2010). The species was described from specimens collected at the Poti and Parnaíba Rivers in Piauí state, Brazil. After its original description, only citations in systematic lists were cited in the literature and the biology of the species remains unknown.

As opposed to other potamotrygonid species, which are found in humid Neotropical areas, P. signata occurs only in a river system mostly situated in the semi-arid Caatinga biome, characterized by an extreme hydrological cycle, with a long and severe dry season. This condition renders most tributaries of the right bank of the Parnaíba River intermittent (Maltchik, 1999; Rosa et al., 2003). The hydrological perturbation is the major structuring factor of the semi-arid aquatic ecosystems, determining the ecological succession of the communities (Maltchik, 1999). As such, it should also affect the availability of macroinvertebrates for intermediate-level predators, such as the potamotrygonid freshwater stingrays.

The aim of this study was to characterize the overall diet of $P$. signata based on the analysis of stomach contents, and to provide preliminary information on intraspecific diet variability between sexes and maturity stages. This is the first study to document the diet of this endemic species, and may be of fundamental importance to understand the trophic relationships in the ecosystem and for decision making in conservation measures.

\section{Material and Methods}

Four 15-day sampling periods were taken between 2009 and 2010, in the dry and rainy seasons. Specimens were collected using seine nets, gillnets, spears and casting nets in accordance with Charvet-Almeida (2006) and Almeida et al. (2010). The gillnet was the most widely used technique, and the nets were checked every 3 hours throughout the day (12 hours). The other techniques were complementary and not standardized.

The specimens were captured in four places in the Parnaíba River basin, in Piauí state, northeastern Brazil: Picos ( $7^{\circ} 9^{\prime} \mathrm{S}$ and $\left.41^{\circ} 36^{\prime} \mathrm{W}\right)$, Valença do Piauí (5 $5^{\circ} 48^{\prime} \mathrm{S}$ and $41^{\circ} 36^{\prime} \mathrm{W}$ ), Santa Cruz dos Milagres ( $5^{\circ} 48^{\prime} \mathrm{S}$ and $41^{\circ}$ $57^{\prime} \mathrm{W}$ ) and Uruçuí (7' $13^{\prime} \mathrm{S}$ and $\left.44^{\circ} 32^{\prime} \mathrm{W}\right)$. A collecting permit (number 19868-1) limited to 60 specimens was issued by the Brazilian Institute for the Environment and Natural Renewable Resources (IBAMA) and by the Chico Mendes Institute of Biodiversity Conservation (ICMBio).

Specimens were killed by excessive use of anesthetic and eviscerated through a ventral semi-circular incision. The ends of the stomachs of each specimen were tied prior to its removal, at the level of cardiac and pyloric valves, to prevent the loss of stomach contents. All stomachs were tagged and injected with buffered formaldehyde solution $(10 \%)$ to fix the food items, and later preserved in ethanol solution $(70 \%)$.

In the laboratory, each stomach was externally washed under running water, the stomachs were tied, the walls were cut and the stomach content was emptied into a Petri plate. The excess liquid was removed with a paper towel and food items were weighed to the nearest milligram $(\mathrm{mg})$.

Food items were identified to the lowest taxonomic category using a stereoscopic microscope (Leica, MZ12). Empty stomachs were not considered in the calculation of how often food items were found, as was plant matter which was more likely to have been ingested, as in other potamotrygonids (Charvet-Almeida, 2006; Garrone-Neto, 2009; Almeida et al., 2010).

The following variables were calculated for each food item: a) Percentage frequency of occurrence $(\% \mathrm{FO}=100 \times$ $\mathrm{Fi} / \mathrm{n}$, where: $\mathrm{Fi}=$ number of times the food item occurred; and $\mathrm{n}=$ total number of stomachs with food items); $\mathrm{b}$ ) Percentage by number $(\% \mathrm{~N}=100 \times \mathrm{Ni} / \mathrm{n}$, where: $\mathrm{Ni}=$ number of items of each taxon; and $n=$ total number of items of all taxa); and c) percentage by weight $(\% \mathrm{~W}=100 \times \mathrm{Wi} / \mathrm{n}$, where: $\mathrm{Wi}=$ total weight of one item (taxon); and $\mathrm{n}=$ sum of all the weights of all stomach contents).

Based on the preceding percentages, a modified Index of Relative Importance - IRI (Pinkas et al., 1971) was calculated, where the volume percentage was replaced by weight percentage, due to the difficulty in calculating the volume of small items for each stomach (Hacunda, 
1981). The Index of Relative Importance equation is: $\mathrm{IRI}=\% \mathrm{FO} \times(\% \mathrm{~N}+\% \mathrm{~W})$.

The IRI was also transformed in percentage (\%IRI) according to Cortés (1997).

Sexual maturity in females was determined by observing embryos or the presence of ovarian follicles with diameters larger than $10 \mathrm{~mm}$, and in males by the degree of rigidity of the clasper and the presence of semen. Accordingly, the specimens were grouped into immature and mature categories, in order to establish ontogenetic comparisons of the diet (Charvet-Almeida, 2006; Rincon, 2006).

The levels of stomach repletion were observed and classified according to the following values: $0=$ empty, $1=1 / 4$ full, $2=$ half full, $3=3 / 4$ full and $4=$ full. The repletion levels were compared between immature and mature individuals and between males and females by the paired Chi-Square Test $\left(\chi^{2}\right.$, degree of freedom $\mathrm{DF}=1$; level of significance $\mathrm{P}<0.05$ ) (Zar, 1999; Ayres et al., 2003).

The digestion degree of food items was observed according to the scale proposed by Zavala-Camin (1996), as follows: 1 = undigested food; 2 = external parts partially digested; 3 = external parts and muscle mass partially digested; $4=$ only the axial skeleton and part of muscle mass present; and $5=$ only fragments can be observed.

\section{Results}

In total, 59 stomachs of $P$. signata (36 females/23 males) were analyzed, of which $56(94.91 \%)$ had food items, and three stomachs were empty. The analysis of stomach contents revealed 17 food items belonging to 13 taxonomic orders (Table 1). Diptera larvae was the most representative in $\% \mathrm{FO}, \% \mathrm{~N}, \% \mathrm{~W}$ and $\%$ IRI. The second and third most representative insect orders in \%IRI were Ephemeroptera and Odonata nymphs, respectively.
Non-insect prey categories combined represented less than one \%IRI.

Prey families identified in the analysis were: Ceratopogonidae, Chironomidae, Ephemeridae, Siphlonuridae, Gomphidae and Belostomatidae (Insecta); Cymothoidae and Palaemonidae (Malacostraca); Pisidiidae (Bivalvia); Pleuroceridae (Gastropoda) and Sciaenidae (Osteichthyes). Some items were identified at the genus or species level: Chironomus sp. and Aphylla sp. (Insecta); Telota sp. (Malacostraca); Plagioscion squamosissimus (Heckel, 1840) (Osteichthyes).

Due to the sharp dietary dominance of Insecta, data exclusively of this class were grouped and divided into four categories: Diptera, Ephemeroptera, Odonata and other insects (comprising Hemiptera, Trichoptera and Plecoptera). The latter was grouped this way because the sum of the \%IRI of each component did not exceed $0.15 \%$.

Considering the diets separated by sex, Diptera and Ephemeroptera were the main items consumed by females, with Ephemeroptera presenting higher $\% \mathrm{FO}$ and $\% \mathrm{~W}$, while Diptera showed a higher $\% \mathrm{~N}$ (Table 2). Diptera proved to be the main item consumed by males, with a $\% \mathrm{FO}, \% \mathrm{~N}$ and $\% \mathrm{~W}$ equal to or larger than other items (Table 2).

When the diets were separated by the ontogenetic stage, immature individuals showed a feeding dominance for Diptera, with a $\% \mathrm{FO}, \% \mathrm{~N}$ and $\% \mathrm{~W}$ larger or equal to other items. In mature individuals, Diptera accounted for a higher $\% \mathrm{~N}$ and $\% \mathrm{~W}$, while Ephemeroptera showed a higher \%FO (Table 2).

A smaller dominance of Ephemeroptera was observed in the diet of immature females $(56.21 \%$ IRI), while for immature males, Diptera had the greatest importance (88.80\% IRI). The item Odonata (5.42\% IRI) and other insects $(0.40 \%$ IRI) appeared in the diet of mature females but not in immature females.

Table 1. Stomach content analysis for Potamotrygon signata $(\mathrm{n}=56)$ indicating the percentage frequency of occurrence $(\% \mathrm{FO})$, percentage by number $(\% \mathrm{~N})$, percentage by weight $(\% \mathrm{~W})$, Index of Relative Importance (IRI) and its respective percentage (\%IRI) for each taxonomic order identified.

\begin{tabular}{llrrrrr}
\hline \multicolumn{1}{c}{ Class } & \multicolumn{1}{c}{ Order } & \% FO & \% N & \% W & \multicolumn{1}{c}{ IRI } & \% IRI \\
\hline Arachnida & Acariformes & 1.79 & 0.11 & 0.00 & 0.21 & 0.00 \\
Insecta & Diptera & 87.50 & 56.48 & 39.39 & 8388.04 & $\mathbf{6 0 . 6 4}$ \\
& Ephemeroptera & 89.29 & 26.40 & 27.32 & 4796.60 & $\mathbf{3 4 . 6 8}$ \\
& Odonata & 28.57 & 5.42 & 11.73 & 489.95 & 3.54 \\
& Hemiptera & 1.79 & 0.04 & 0.10 & 0.24 & 0.00 \\
& Trichoptera & 1.79 & 0.04 & 0.02 & 0.11 & 0.00 \\
Malacostraca & Plecoptera & 7.14 & 0.91 & 2.06 & 21.24 & 0.15 \\
& Decapoda & 7.14 & 0.27 & 9.41 & 69.10 & 0.50 \\
Branchiopoda & Isopoda & 1.79 & 0.04 & 0.02 & 0.10 & 0.00 \\
Bivalvia & Conchostraca & 3.57 & 9.20 & 6.08 & 54.60 & 0.39 \\
Gastropoda & Veneroida & 3.57 & 0.72 & 0.53 & 4.47 & 0.03 \\
Osteichthyes & Caenogastropoda & 3.57 & 0.34 & 0.10 & 1.56 & 0.01 \\
Total & Perciformes & 1.79 & 0.04 & 3.24 & 5.85 & 0.04 \\
\hline
\end{tabular}

The numbers in bold correspond to the highest values. 
Table 2. Composition of the diet of females $(n=33)$, males $(n=23)$, immature $(n=7)$ and mature $(n=49)$ of Potamotrygon signata, represented by Relative Frequency of Occurrence (\%FO), Numerical Percentage $(\% \mathrm{~N})$, Weight Percent $(\% \mathrm{~W})$ and Index of Relative Importance (IRI and \%IRI) for the class Insecta.

\begin{tabular}{|c|c|c|c|c|c|}
\hline & $\% \mathrm{FO}$ & $\% \mathbf{N}$ & $\% \mathrm{~W}$ & IRI & $\%$ IRI \\
\hline \multicolumn{6}{|l|}{ Female } \\
\hline Diptera & 87.88 & 49.96 & 32.96 & 7286.92 & 47.12 \\
\hline Ephemeroptera & 90.91 & 39.22 & 42.20 & 7401.85 & 47.86 \\
\hline Odonata & 24.24 & 8.99 & 20.82 & 722.67 & 4.67 \\
\hline Other insects & 9.09 & 1.83 & 4.02 & 53.17 & 0.34 \\
\hline Total & 212.12 & 100 & 100 & 15464.6 & 100 \\
\hline \multicolumn{6}{|l|}{ Male } \\
\hline Diptera & 86.96 & 79.98 & 75.55 & 13524.29 & 79.56 \\
\hline Ephemeroptera & 86.96 & 17.43 & 19.93 & 3249.06 & 19.11 \\
\hline Odonata & 34.78 & 2.39 & 4.02 & 223.05 & 1.31 \\
\hline Other insects & 4.35 & 0.19 & 0.50 & 3.02 & 0.02 \\
\hline Total & 213.05 & 100 & 100 & 16999.42 & 100 \\
\hline \multicolumn{6}{|l|}{ Immature } \\
\hline Diptera & 100 & 76.70 & 71.59 & 14829.34 & 76.20 \\
\hline Ephemeroptera & 100 & 20.07 & 25.33 & 4540.59 & 23.33 \\
\hline Odonata & 14.29 & 3.23 & 3.07 & 90.01 & 0.46 \\
\hline Other insects & - & - & - & - & - \\
\hline Total & 214.29 & 100 & 100 & 19459.94 & 100 \\
\hline \multicolumn{6}{|l|}{ Mature } \\
\hline Diptera & 85.71 & 61.45 & 47.04 & 9299.56 & 59.06 \\
\hline Ephemeroptera & 87.76 & 30.85 & 34.57 & 5740.58 & 36.46 \\
\hline Odonata & 30.61 & 6.45 & 15.47 & 670.84 & 4.26 \\
\hline Other insects & 8.16 & 1.25 & 2.92 & 34.08 & 0.22 \\
\hline Total & 212.24 & 100 & 100 & 15745.06 & 100 \\
\hline
\end{tabular}

The numbers in bold correspond to the highest values.

Table 3. Chi-Square Test $\left(\chi^{2}\right)$ to the repletion levels between sex and maturity categories of Potamotrygon signata.

\begin{tabular}{|c|c|c|c|c|c|c|c|c|}
\hline \multirow{2}{*}{ Repletion level } & \multicolumn{2}{|c|}{$\operatorname{Sex}(n)$} & \multirow{2}{*}{$\chi^{2}$} & \multirow{2}{*}{$\mathbf{p}$} & \multicolumn{2}{|c|}{ Sexual maturity (n) } & \multirow{2}{*}{$\chi^{2}$} & \multirow{2}{*}{$\mathbf{p}$} \\
\hline & Female & Male & & & Immature & Mature & & \\
\hline $\mathbf{0}$ & 3 & 0 & 3.00 & 3.000 & 0 & 3 & 3.00 & 3.000 \\
\hline 1 & 10 & 6 & 1.00 & 0.453 & 3 & 13 & 6.25 & 0.024 \\
\hline 2 & 10 & 8 & 0.222 & 0.813 & 1 & 17 & 14.222 & 0.001 \\
\hline 3 & 8 & 3 & 2.273 & 0.228 & 1 & 10 & 7.364 & 0.016 \\
\hline 4 & 5 & 6 & 0.091 & 1.000 & 2 & 9 & 4.455 & 0.070 \\
\hline Total & 36 & 23 & - & - & 7 & 52 & - & - \\
\hline
\end{tabular}

The numbers in bold correspond to the highest values.

The repletion levels 1 and 2 were the most common in females $(27.78 \%$ each) while level 2 was the most common for males $(34.78 \%)$. Regarding sexual maturity, the main level was $1(42.86 \%)$ for immature and $2(32.69 \%)$ for mature individuals (Table 3 ).

The degree of digestion 3 was the most common $(44.30 \%)$, followed by $4(20.07 \%)$. When sexes were considered separately, the degree of digestion 3 was the most frequent for both females $(38.76 \%)$ and males $(50.16 \%)$.
For immature and mature individuals, the most frequent category was also 3 (61.82\% and $40.05 \%$, respectively).

\section{Discussion}

Potamotrygon signata shows insectivorous feeding habits, consuming mainly Diptera larvae and Ephemeroptera nymphs. An essentially insectivorous diet was also reported for the congeners P. orbignyi (Lasso et al., 1996; Rincon, 
2006; Charvet-Almeida, 2006) and P. motoro from the upper Paraná River (Silva and Uieda, 2007). On the Marajó Island, at the lower Amazon drainage, P. motoro also consumed insects, but decapod crustaceans and fish were the dominant items (Almeida et al., 2010).

Despite the lack of data on the feeding ecology of extinct freshwater stingrays, we may assume that at least in the Potamotrygonidae, the insectivorous habit found mainly in juveniles of extant species, but also in the adults of some species, represents an evolutionary shift from the basal diet composed of hard-shelled invertebrates in marine batoids (Carroll, 1987), dominated by macrocrustaceans (Belleggia et al., 2008; Moura et al., 2008; Payán et al., 2011).

The essentially insectivorous diet of $P$. signata and of the congener P. orbignyi (Moro et al., 2011) in the Caatinga semi-arid portion of the Parnaíba basin is possibly adaptive, because fish populations, and consequently their availability as prey, are subject to strong seasonal variation according to the hydrological cycle. The third stingray species in the Parnaíba basin, P. motoro, which feeds mainly on mollusks, crustaceans and fish, has not been found so far in semi-arid stretches, known only from the permanently flowing tributaries of the left bank of the Parnaíba River in Maranhão State, which drain the Cerrado biome (personal observation of G. Moro). This species is also found in tributaries and marginal lakes of the Mearim River basin in Maranhão State (Pinto, 1987; Soares, 2005).

A significant impact affecting the conservation of freshwater fauna, particularly for endemic insectivorous species such as $P$. signata, is the ubiquitous use of chemical defensives that follows the recent expansion of agricultural and cattle ranching in the area.

The difference in diets between males and females may be related to the viviparous reproductive strategy (matrotrophic viviparity with trophonemata) used by freshwater stingrays (Charvet-Almeida et al., 2005). In this sense, some items may contribute to an increased supply of nutrients during the reproductive period and may be directly aimed at females in the feeding process (Almeida et al., 2010). Nonetheless, sexual differences in the diet were also observed in immature individuals of $P$. signata in the present study.

The observed sexual differences may reflect a differential feeding behavior or feeding niche between males and females and/or a strategy for lowering the intraspecific competition. These differences cannot be accounted for by spatial segregation between males and females, a common feature in marine elasmobranchs (Pratt and Carrier, 2005), because both sexes co-occurred in the sampled locations. On the other hand, sexual dimorphism in potamotrygonids is observed in adults only (Charvet-Almeida et al., 2005), and would not explain dietary differences between immature males and females.

Charvet-Almeida (2006) observed differences in the diets of male and female Potamotrygon leopoldi Castex and Castello, 1970 from the Xingu River in Brazil and pointed out that pregnant females could search for specific nutrient-rich prey. However, Almeida et al. (2010) did not observe sexual differences in the diet of $P$. motoro on the Marajo Island in Brazil. Similar findings, reporting either the presence or absence of sexual differences among congeneric species of marine batoids, were cited by PoloSilva and Grijalba-Bendeck (2008) and Payán et al. (2011) for Rhinobatos and Belleggia et al. (2008) for Bathyraja.

Ontogenetic differences in dietary habits and between immature and mature individuals have been reported for freshwater stingrays by Charvet-Almeida (2006) and Silva and Uieda (2007), as well as for marine batoids (Muto et al., 2001; Moura et al., 2008).

The main items eaten by immature freshwater stingrays are mollusks, crustaceans and insect larvae, while mature individuals consume fish and crabs (Achenbach and Achenbach, 1976). Rincon (2006) found an ontogenetic diet variation in P. orbignyi at the Paranã-Tocantins River system in Brazil, with immature individuals feeding on Diptera larvae during the initial life stages and, along the ontogeny, replacing that item mainly by Ephemeroptera nymphs, and including other insects in the diet (Odonata, Trichoptera and Coleoptera). Garrone-Neto (2009) recorded an insectivore diet during the first year of life in $P$. motoro and $P$. falkneri in the upper Paraná River, and the inclusion of gastropod mollusks, shrimps and fish in their diet later in the development.

Ontogenetic differences in tooth morphology and in oral musculature of freshwater stingrays may be related to and enable the transitions in food habits (Pântano-Neto and Souza, 2002). The changes are likely associated with energy requirements of each developmental stage (Charvet-Almeida, 2006).

In this study, only three empty stomachs were found, however, most had low repletion levels. Wetherbee et al., (1990) mentioned that high percentages of empty stomachs or low levels of repletion are common in marine elasmobranchs. The results of other studies confirm that this also seems to be a common feature for freshwater stingrays (CharvetAlmeida, 2006; Rincon, 2006; Almeida et al. 2010).

The present study revealed both ontogenetic and sexual differences in the diet of $P$. signata, as indicated in previous studies of other species of the genus. The essentially insectivorous habit of the species, which parallels that of the congener P.orbignyi in the same habitat, is possibly related to the ecological features of the Parnaíba River basin, mostly situated in the semi-arid Caatinga biome. The restricted sample size and sampling period precluded the assessment of temporal variation of the diet in the present study. This could be an interesting subject for future research due to the extreme hydrologic perturbation of the Parnaíba River tributaries in the Caatinga biome, where the aquatic community structure and prey availability possibly show high seasonal variation (Moro et al., 2011).

Acknowledgements - The authors are grateful to the specialists for their assistance in identifying the food items: Luiz Lopez, Telma Dias, Anne Gondim, Joafrancio Araujo and Telton Ramos. We would like to thank Luis Lucifora for critically 
reviewing the manuscript. The paper also benefited from the comments of two anonymous reviewers. The first author is thankful to the Conselho Nacional de Desenvolvimento Científico $(\mathrm{CNP} q)$ for providing an MSc scholarship. Ricardo $\mathrm{S}$. Rosa would also like to thank $\mathrm{CNPq}$ for a grant funding his elasmobranch studies.

\section{References}

ACHENBACH, GM. and ACHENBACH, SVM., 1976. Notas acerca de algunas especies de raya fluvial (Batoidei, Potamotrygonidae), que frecuentan el sistema hidrográfico del río Paraná medio en el Departamento La Capital (Santa Fe-Argentina). Comunicaciones del Museo Provincial de Ciencias Naturales "Florentino Ameghino", vol. 8, p. 1-34.

AGUIAR, AA. and VALENTIN, JL., 2010. Biologia e ecologia alimentar de elasmobrânquios (Chondrichthyes: Elasmobranchii): uma revisão dos métodos e do estado da arte no Brasil. Oecologia Australis, vol. 14, p. 464-489. http://dx.doi.org/10.4257/ oeco.2010.1402.09

ALMEIDA, MP., LINS, PMO., CHARVET-ALMEIDA, P. and BARTHEM, RB., 2010. Diet of the fresh water stingray Potamotrygon motoro (Chondrichthyes: Potamotrygonidae) on Marajó Island (Pará, Brazil). Revista Brasileira de Biologia = Brazilian Journal of Biology, vol. 70, no. 1, p. 155-162. PMid:20231973.

AYRES, M., AYRES JUNIOR, M., AYRES, DL. and SANTOS, AS., 2003. BioEstat 5.0: aplicações estatísticas nas áreas das ciências biológicas e médicas. Belém: Sociedade Civil Mamirauá. 291 p.

BELLEGGIA, M., MABRAGAÑA, E., FIGUEROA, DE., SCENNA, LB., BARBINI, SA. and DÍAZ-ASTARLOA, JM., 2008. Food habits of the broad nose skate, Bathyraja brachyurops (Chondrichthyes, Rajidae), in the south-west Atlantic. Scientia Marina, vol. 72, p. 701-710. http://dx.doi.org/10.3989/scimar.2008.72n4701

CARROLL, RC., 1987. Vertebrate Paleontology and Evolution. New York: W. H. Freeman and Co. 698 p.

CARVALHO, MR., LOVEJOY, NR. and ROSA, RS., 2003. Family Potamotrygonidae (river stingrays). In REIS, RE., FERRARIS JUNIOR, CJ., and KULLANDER SO. (Eds.). Checklist of freshwater fishes of South and Central America. Porto Alegre: Edipucrs. p. 22-29.

CHARVET-ALMEIDA, P., 2006. História Natural e Conservação das Raias de Água Doce (Chondrichthyes: Potamotrygonidae), no Médio Rio Xingu, Área de Influência do Projeto Hidrelétrico de Belo Monte (Pará, Brasil). João Pessoa: Universidade Federal da Paraíba. 475 p. Tese de Doutorado.

CHARVET-ALMEIDA, P., ARAÚJO, MLG. and ALMEIDA, MP., 2005. Reproductive aspects of freshwater stingrays (Chondrichthyes: Potamotrygonidae) in the Brazilian Amazon Basin. Journal of Northwest Atlantic Fishery Science, vol. 35, p. 165-171. http://dx.doi.org/10.2960/J.v35.m502

CORTÉS, E., 1997. A critical review of methods of studying fish feeding based on analysis of stomach contents: application to elasmobranch fishes. Canadian Journal of Fisheries and Aquatic Sciences, vol. 54, p. 726-738. http://dx.doi.org/10.1139/ cjfas-54-3-726

GARRONE-NETO, D., 2009. História natural, diversidade e distribuição de raias na região do alto rio Paraná, Brasil. Botucatu: Universidade Estadual Paulista "Júlio De Mesquita Filho". 204 p. Tese de Doutorado.
GARRONE-NETO, D. and SAZIMA, I., 2009a. The more stirring the better: cichlid fishes associate with foraging potamotrygonid rays. Neotropical Ichthyology, vol. 7, p. 499-501. http://dx.doi. org/10.1590/S1679-62252009000300018

-, 2009b. Stirring, charging, and picking: hunting tactics of potamotrygonid rays in the upper Paraná River. Neotropical Ichthyology, vol. 7, p. 113-116.

HACUNDA, JS., 1981. Trophic relationships among demersal fishes in a coastal area of the Gulf of Maine. Fishery Bulletin, vol. 79, p. 775-788.

HYSLOP, EJ., 1980. Stomach contents analysis - a review of methods and their application. Journal of Fish Biology, vol. 17, p. 411-429. http://dx.doi.org/10.1111/j.1095-8649.1980.tb02775.x

LASSO, CA., RIAL, AB. and LASSO-ALCALÁ, O., 1996. Notes on the biology of the freshwater stingrays Paratrygon aiereba (Müller andHenle, 1841) and Potamotrygon orbignyi (Castelnau, 1855) (Chondrichthyes: Potamotrygonidae) in the Venezuelan llanos. Aqua Journal of Ichthyology and Aquatic Biology, vol. 2, p. 39-52.

LONARDONI, AP., GOULART, E., OLIVEIRA, EF. and FEDATTO-ABELHA, MC., 2006. Feeding habitats and trophic overlap of the freshwater stingrays Potamotrygon falkneri and Potamotrygon motoro (Chondrichthyes, Potamotrygonidae) in the upper Parana River floodplain, Brazil. Acta Scientiarum Biological Sciences, vol. 28, p. 195-202.

LONARDONI, A., OLIVEIRA, PEF. and GOULART, E., 2009. Trophic ecomorphology of Potamotrygon falkneri and Potamotrygon motoro (Chondrichthyes - Potamotrygonidae) on the upper Paraná river floodplain, Brazil. Pan-American Journal of Aquatic Sciences, vol. 4, p. 436-445.

MALTCHIK, L., 1999. Ecologia de rios intermitentes tropicais. In POMPEO, MLM. (Ed.). Perspectivas da limnologia no Brasil. São Luiz: Editora União. p. 77-90.

MORO, G., CHARVET, P. and ROSA, RS., 2011. Aspectos da alimentação da raia de água doce Potamotrygon orbignyi (Chondrichthyes: Potamotrygonidae) da bacia do rio Parnaíba, Nordeste do Brasil. Revista Nordestina de Biologia, vol. 20, p. 47-57.

MOURA, T., FIGUEIREDO, I., FARIAS, I., SERRA-PEREIRA, B., NEVES, A., BORGES, MF. and GORDO, LS., 2008. Ontogenetic dietary shift and feeding strategy of Raja undulata Lacepède, 1802 (Chondrichthyes: Rajidae) on the Portuguese continental shelf. Scientia Marina, vol. 72, p. 311-318.

MUTO, EY., SOARES, LSH. and GOITEIN, R., 2001. Food resource utilization of the skates Rioraja agassizii (Müller and Henle, 1841) and Psammobatis extenta (Garman, 1913) on the continental shelf off Ubatuba, South- Eastern Brasil. Revista Brasileira de Biologia = Brazilian Journal of Biology, vol. 61, p. 217-238. PMid:11514890.

PÂNTANO-NETO, J. and SOUZA, A., 2002. Anatomia da musculatura oro-branquial associada à alimentação de duas espécies de raias de água doce (Potamotrygonidae; Elasmobranchii). Publicações Avulsas Instituto Pau Brasil de História Natural, vol. 5, p. 53-65.

PAYÁN, LF., NAVIA, AF., RUBIO, EA. and MEJÍA-FALLA, PA., 2011. Biología de la raya guitarra Rhinobatos leucorhynchus (Günther, 1867) (Rajiformes: Rhinobatidae) en el Pacífico colombiano. Latin American Journal of Aquatic Research, vol. 39, p. 286-296. 
PINKAS, L., OLIPHANT, MS. and IVERSON, ILK., 1971. Food habits of albacore, bluefin tuna and bonito in Californian waters. California Fish and Game, vol. 152, p. 1-105.

PINTO, JA., 1987. Biologia de Potamotrygon motoro (Pisces: Rajiformes) do complexo lagunar de Viana - Maranhão. São Luís: Universidade Federal do Maranhão. 45 p. Monografia.

POLO-SILVA, CJ. and GRIJALBA-BENDECK, LM., 2008. Espectro trófico de la raya guitarra Rhinobatos percellens (Walbaum, 1792) (Elasmobranchii: Rhinobatidae) en Santa Marta, Caribe Colombia. Memoria de la Fundación La Salle de Ciencias Naturales, vol. 68, p. 21-33.

PRATT, HL. and CARRIER, JC., 2005. Elasmobranch courtship and mating behavior. In HAMLETT, WC. (Ed.). Reproductive Biology and Phylogeny of Chondrichthyes: sharks, batoids and chimaeras. Enfield: Science Publishers. p. 129-169.

RINCON, G., 2006. Aspectos taxonômicos, alimentação e reprodução da raia de água doce Potamotrygon orbignyi (Castelnau, 1855) (Elasmobranchii: Potamotrygonidae) no rio Paraná - Tocantins. Rio Claro: Universidade Estadual Paulista "Júlio De Mesquita Filho". 132 p. Tese de Doutorado.

ROSA, RS., CASTELLO, HP. and THORSON, TB., 1987. Plesiotrygon iwamae, a new genus and species of Neotropical freshwater stingray (Chondrichthyes: Potamotrygonidae). Copeia, vol. 1987, p. 447-458. http://dx.doi.org/10.2307/1445783

ROSA, RS., MENEZES, NA., BRITSKI, HA., COSTA, WJEM. and GROTH, F., 2003. Diversidade, padrões de distribuição e conservação dos peixes da Caatinga. In LEAL, IR., TABARELLI,
M. and SILVA, JMC. (Eds.). Ecologia e Conservação da Caatinga. Recife: Editora Universitária da UFPE. p. 135-162.

ROSA, RS., CHARVET-ALMEIDA, P. and QUIJADA, CCD., 2010. Biology of the South American potamotrygonid stingrays. In CARRIER, JC., MUSICK, JA. and HEITHAUS, MR. (Eds.). Sharks and their relatives II: Biodiversity, adaptive physiology and conservation. New York: Taylor and Francis Group. p. 241-286.

SHIBUYA, M., ARAÚJO, MLG. and ZUANON, JAS., 2009. Analysis of stomach contents of freshwater stingrays (Elasmobranchii, Potamotrygonidae) from the middle Negro River, Amazonas, Brazil. Pan-American Journal of Aquatic Sciences, vol. 4, p. 466-475.

SILVA, TB. and UIEDA VS., 2007. Preliminary data on the feeding habits of the freshwater stingrays Potamotrygon falkneri and Potamotrygon motoro (Potamotrygonidae) from the Upper Paraná River basin, Brazil. Biota Neotropica, vol. 7, p. 221-226.

SOARES, EC., 2005. Peixes do Mearim. São Luís: Instituto Geia. $142 \mathrm{p}$.

WETHERBEE, BM., GRUBER, SH. and CORTÉS, E., 1990. Diet, feeding habits, digestion and consumption in sharks, with special reference to the lemon shark, Negaprion brevirostris. In PRATT, HL., GRUBER, SH. and TANIUCHI, T. (Eds.). Elasmobranch as Living Resources: advances in biology, ecology and systematics, and the status of fisheries. Springfield: NOAA Technical Report. p. 29-47.

ZAR, JH., 1999. Biostatistical Analysis. New Jersey: Prentice Hall. 123 p.

ZAVALA-CAMIN, LA., 1996. Introdução aos estudos sobre alimentação natural em peixes. Maringá: Eduem. 129 p. 
